DOI: $10.15193 /$ zntj/2020/125/363

\author{
EGLI C. GEORGIADOU, GEORGE A. MANGANARIS, \\ VASILEIOS FOTOPOULOS
}

\title{
THE DIVERSE ROLES OF VITAMIN E, ITS OCCURRENCE AND REGULATION IN DIFFERENT PLANT TISSUES
}

\begin{abstract}
Sum m a r y
Fruits and vegetables contain vitamins, dietary fibre and phytochemicals, which promote human health. Specifically vitamins are major bioactive compounds, divided in water-soluble (vitamins B and C) and fat-soluble (vitamins A, D, E and K) ones, having strong antioxidant potential and limiting several diseases, including cancer and cardio-vascular diseases. Furthermore, vitamins play a key role in plant protection against abiotic and biotic stress factors. Vitamin $\mathrm{E}$ is a group of eight fat-soluble compounds known as tocochromanols, which are synthesized exclusively by photosynthetic organisms. Tocochromanols are categorised into two groups - tocopherols and tocotrienols. Each group contains four forms identified by prefixes $\alpha$-, $\beta$-, $\gamma$ - and $\delta$-, yielding a total of eight forms. Vitamin $\mathrm{E}$ is an essential, lipid-soluble antioxidant in the human diet, protecting from cancer, diabetes, cardiovascular and neurological diseases. This review summarizes the recent developments in understanding the variety of roles of vitamin $\mathrm{E}$ as well as its major genetic regulatory pathways in plants. In addition, a comprehensive mapping of vitamin $\mathrm{E}$ occurrence is presented in different plant tissues, organelles and horticultural crop species, as well as throughout different stages of fruit development and at postharvest.
\end{abstract}

Key words: tocopherols, tocotrienols, tocochromanols, vitamin E

\section{Introduction}

Vitamins are a small group of organic compounds that are essential in the human diet. Humans are not able to synthesize these compounds so they must be obtained through diet. There are 13 compounds classified as vitamins. They can be broadly classified into fat-soluble (A, D, E and K) and water-soluble (vitamin B complex: B1, B2, B3, B5, B6, B8, B9, B12 and vitamin C) - Fig. 1. These compounds are biosynthesized by bacteria, fungi and plants and their main function is acting as cofactors or coen-

E. C. Georgiadou, G. A. Manganaris, V. Fotopoulos, Department of Agricultural Sciences, Biotechnology and Food Science, Cyprus University of Technology, 3603, Limassol, Cyprus.

Contact: vassilis.fotopoulos@cut.ac.cy 
zymes in various enzymatic reactions. Vitamins from plants (fruit and vegetables) are very significant because of their impact on human health. Due to their redox chemistry and role as enzymatic factors, vitamins are imperative for the metabolism of animals and plants. Some compounds play other particular roles such as antioxidants (vitamins $\mathrm{C}$ and $\mathrm{E}$ ), substances that improve the functioning of the eyesight ( $\beta$-carotene) or as a (pre-) hormone involved in calcium and phosphorus homeostasis in the blood stream (vitamin D). Therefore, human nutritional health is dependent on plant food either directly or indirectly (by eating animals that feed on plants). As vitamin compounds do not provide energy, they are needed in small amounts by humans. Vitamin deficiencies cause diseases that can be serious [17].

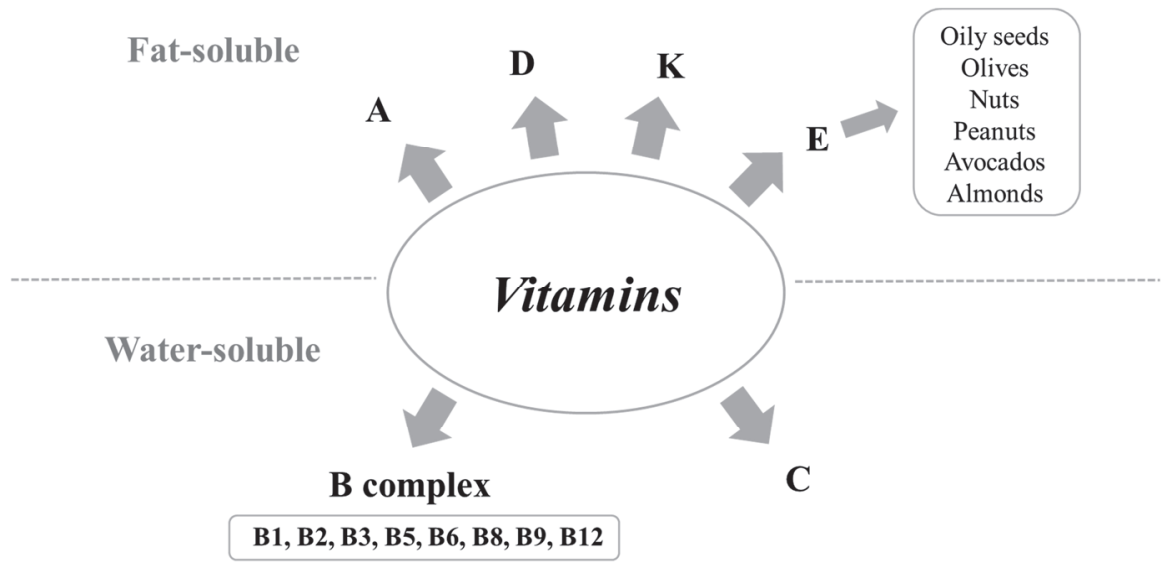

Fig. 1. Fat and water soluble vitamins

Rys. 1. Witaminy rozpuszczalne w thuszczach i wodzie

Source / Źródło: the author's own study based on [17] / opracowanie własne na podstawie [17]

Vitamin E (tocochromanols) are considered to be lipophilic bioactive compounds. It has been claimed that vitamin E protects against diabetes and neurological diseases [2] and reduces the risk for Alzheimer's disease [51]. Furthermore, vitamin E is a natural antioxidant [9] fighting against oxidative damage because it quenches polyunsaturated free radicals and as a result breaks the chain reaction of lipid peroxidation. It also maintains the cardiovascular system and protects against cancer and other illnesses [35].

Humans cannot synthesize vitamin E, so sufficient quantity must be obtain through the diet that is mainly from plants that produce oil. The levels of vitamin $\mathrm{E}$ differ from plant to plant in composition, activity and quantity. Deficiency in vitamin $\mathrm{E}$ can cause hemolytic anemia in premature babies and neurological and ophthalmological disorders in children. In developing countries vitamin E deficiency is more com- 
mon than in developed ones, which is only observed in specific conditions as premature babies, digestive pathology and genetic pathology [12].

The regulation of vitamin metabolism in plants has been extensively studied in order to develop new cultivars with high nutritional content. Using new technological approaches, attempts are being made to identify vitamin-rich alleles in order to introduce these to elite cultivars.

The aim of this paper is to present the various roles of vitamin $E$ in plants as well as the importance of exploiting vitamin E metabolism in plants.

\section{The diverse roles of vitamin $\mathbf{E}$ in fruits and vegetables}

Vitamin E (tocochromanols) is a lipophilic antioxidant consisting of tocopherols and tocotrienols, which are compounds synthesized by photosynthetic organisms. Tocochromanols are essential for the dietary needs of humans [40]. There are eight distinct forms of vitamin $\mathrm{E}$ classified in two chemical groups $(\alpha-, \beta-, \gamma-, \delta$-tocopherols and $\alpha-, \beta-, \gamma-, \delta$-tocotrienols, respectively). These differ considerably in their vitamin $\mathrm{E}$ activity in vivo, the highest activity being shown by $\alpha$-tocopherol on a molar basis and the most abundant one in nature [17]. Tocopherols and tocotrienols are considered to improve health and are found in fruit and vegetables [17], specifically in oily seeds, olives, nuts, peanuts, avocados and almonds [26, 30].

Vitamin E is a group of compounds with a common chroman-6-ol ring system. The four different tocopherols and tocotrienols found in nature, namely $\alpha, \beta, \gamma$, or $\delta$ (Fig. 2) are determined by the number and positions of methyl groups on this ring system [11]. All the isomers have aromatic rings with hydroxyl group that can provide hydrogen atoms to decrease ROS [26]. Tocopherols have three chiral centers and the natural tocopherols are of the R, R, R configuration, while the chemically synthesized ones are racemic mixtures of eight stereoisomers. The single chiral center in tocotrienols is the only d-isomer in nature and a racemic mixture in synthetic ones. The retention of each compound by the human body is strongly impacted by the number and positions of ring methylation, degree of side chain saturation and stereochemistry [11].

Studies of Munné-Bosch [33] have shown that tocopherols take part in cellular signaling in plants, which demonstrates the role of tocopherols in plant development and stress tolerance. Tocopherols protect plants from losing excessive energy in photosynthetic membranes, detoxify reactive oxygen species (ROS) and lipid radicals, thus protect plants from wasting excessive energy in chloroplasts. In addition, $\alpha$-tocopherol interacts strongly in plants with membrane lipids making the membrane more rigid. Therefore, its presence at high amounts in photosynthetic membranes during specific periods of plant development or stress could be significant in the functioning of the plant regarding membrane stability. 
<smiles>Oc1ccc2c(c1)CCCO2</smiles>

Chroman-6-ol<smiles>[R3]c1c(C)c2c(c([R])c1O)CCC(C)(CCCC(C)([Tl])CCCC(C)CCCC(C)C)O2</smiles><smiles>[R]c1c(C)c2c(c([R])c1O)CCC(C)(CC/C=C(\C)CC/C=C(\C)CCC=C(C)C)O2</smiles>

Fig. 2. Structure of tocopherols and tocotrienols

Rys. 2. Struktura tokoferoli i tokotrienoli

Source / Źródło: the study based on [11] / opracowanie na podstawie [11]

\section{Occurrence and natural variation in vitamin $\mathrm{E}$ in plant tissues}

\section{Vitamin E within plant tissues/cellular compartments}

There is a considerable variation of the content and composition of vitamin $\mathrm{E}$ in plant tissues. Low levels of vitamin $\mathrm{E}$ are found in photosynthetic tissues $(<50 \mu \mathrm{g} / \mathrm{g})$ compared with seeds and particularly oil seeds, which contain 10 - 20 times this level. Fruits and seeds of some species such as oil palm (Elaeis guineensis), oils of which have well known health properties, contain high levels of tocotrienols [13]. Tocopherols have been found in photosynthetic bacteria, fungi, algae, plants and animals, even though animals cannot synthesize them [23]. Tocopherols have also been traced in seeds, flowers (e.g., sepals and petals), roots, tubers, cotyledons, hypocotyls, stems and particularly in leaves of higher plants. Tocopherol content varies in plant tissues with total concentrations ranging from exceptionally low levels in potato tuber $(<1 \mu \mathrm{g} / \mathrm{g}$ dry matter) to very high levels in leaves and seeds ( $>1 \mathrm{mg} / \mathrm{g}$ dry matter) [32].

During oxidative stress and senescence, plastoglobuli increase in number and create linkage groups that are attached to each other and remain continuous with the thylakoid membrane by extensions of the half-lipid bilayer [4].

Even though tocopherols are not usually detected in the cuticular waxes, tocopherols have been found in the wax of Rubus spp. at $1 \div 2 \%$ of total wax. The $\gamma$ - and $\delta$ - 
forms are found at higher concentrations in this wax, while $\alpha$-tocopherol has been detected at very low amounts [44]. In turn, tocotrienols are found in high amounts in seeds [23].

\section{Vitamin $E$ in different fruits and vegetables}

Oily seeds, olives, nuts, peanuts, avocados and almonds are abundant in vitamin E, specifically in $\alpha$-tocopherol [26]. Muzzalupo et al. [34] found that the content of $\alpha$-tocopherol in olive fruit accounts for $67.62 \div 88.60 \%$ of total tocopherol content, depending on their cultivar and developmental stage. In other studies, content of $\alpha$-tocopherol in total tocochromanols in cv. 'Koroneiki' was $85.64 \div 97.87 \%$ [20, 21], in cv. 'Carolea' (in two developmental stages, green and black olive fruit) $-72.00 \div$ $75.60 \%$ [8], while in five Greek olive cultivars ('Mavrelia', 'Koroneiki', 'Kalokerida', 'Lianolia Kerkyras' and 'Kalamon') - $73.09 \div 91.32 \%$ [22]. The difference in comparison with findings by Bodoira et al. [7] is that $\gamma$-tocopherol concentrations (10.68 $\div$ $41.83 \%)$ are only slightly lower than those of $\alpha$-tocopherol $(50.02 \div 81.48 \%)$ at the early stages of olive fruit (cv. 'Arauco'). In tomato fruit Quadrana et al. [36] found that $\alpha$-tocopherol accounts for $83.68 \div 96.87 \%$ of all other tocopherols, while Luby et al. [29] traced $29.64 \div 91.02 \%$ of all other tocochromanols in carrot cultivars. Furthermore, Tlili et al. [48] found that $\alpha$-tocopherol was the predominant compound in all samples $(62.05 \div 75.36 \%)$ of $\alpha$ - and $\gamma$-tocopherol content in commercial capers. The content of tocopherols and tocotrienols in different cultivars of fruit and vegetables is presented in Tab. 1.

\section{Vitamin E during development and ripening}

Several studies have focused on the content of vitamin $\mathrm{E}$ as it changes during the ripening of olive fruit during several developmental stages within a year $[7,8,20,34]$ and across multiple years [21]. The concentrations of $\alpha$-tocopherol generally decreased, both within and across years [21]. During the early stages of olive fruit (cv. 'Arauco') high amounts of tocochromanol content have been found, but as the fruit developed on the tree, there was a decrease [7]. Until reaching breaker stage, the olive fruit has a much higher concentration of tocochromanols compared with later stages, suggesting that the colour alteration of the fruit is linked with modifications in vitamin E content [20]. It was also found that olive oil production and phenolic fraction increase, reaching their highest levels when the mesocarp reaches the end of its development and change colour [3, 7, 10, 38]. Furthermore, carbohydrate metabolism (glycolysis/glyconeogenesis, citrate cycle, fructose, manose and galactose metabolism) is more obvious during the mesocarp development. Interestingly, it was also revealed that during development in grape, which is also a non-climacteric fruit such as olive, tocopherol concentration dropped steadily [25]. The opposite is observed in climacteric fruit 
like mango [45] and tomato [36], which implies that ethylene regulates vitamin E biosynthesis.

Table 1. Vitamin E sources

Tabela 1. Źródła witaminy E

\begin{tabular}{|c|c|c|c|c|c|c|c|c|c|}
\hline \multirow{3}{*}{$\begin{array}{c}\text { Cultivars of fruits } \\
\text { and vegetables } \\
\text { Odmiany owoców i warzyw }\end{array}$} & \multicolumn{4}{|c|}{ Tocopherols / Tokoferole [\%] } & \multicolumn{4}{|c|}{$\begin{array}{c}\text { Tocotrienols } \\
\text { Tokotrienole [\%] }\end{array}$} & \multirow{3}{*}{$\begin{array}{l}\text { Ref. } \\
\text { Lit. }\end{array}$} \\
\hline & $\alpha$ & $\beta$ & $\gamma$ & $\delta$ & $\alpha$ & $\beta$ & $\gamma$ & $\delta$ & \\
\hline & $\begin{array}{l}\text { Range of values } \\
\text { Zakres wartości }\end{array}$ & \multicolumn{7}{|c|}{ Mean value / Wartość średnia } & \\
\hline $\begin{array}{l}\text { 'Arauco' olives } \\
\text { Oliwki 'Arauco' }\end{array}$ & $50.02 \div 81.48$ & 8.92 & 20.54 & - & - & - & - & - & {$[7]$} \\
\hline $\begin{array}{l}\text { 'Carolea' olives } \\
\text { Oliwki 'Carolea' }\end{array}$ & $72.00 \div 75.60$ & 12.20 & 10.10 & 3.75 & - & - & - & - & {$[8]$} \\
\hline $\begin{array}{l}\text { 'Koroneiki' olives } \\
\text { Oliwki 'Koroneiki' }\end{array}$ & $95.64 \div 97.87$ & 0.71 & 0.84 & 0.80 & - & - & 0.94 & - & [20] \\
\hline $\begin{array}{l}\text { 'Koroneiki' olives } \\
\text { Oliwki 'Koroneiki' }\end{array}$ & $85.64 \div 97.50$ & \multicolumn{2}{|c|}{$2.55^{*}$} & 2.16 & 0.70 & \multicolumn{2}{|c|}{$2.44^{* *}$} & - & [21] \\
\hline Greek olives / Oliwki greckie & $73.09 \div 91.32$ & \multicolumn{2}{|c|}{$4.57^{*}$} & 4.06 & 1.27 & \multicolumn{2}{|c|}{$4.59^{* *}$} & 1.47 & [22] \\
\hline Carrots / Marchew & $29.64 \div 91.02$ & \multicolumn{2}{|c|}{$1.59^{*}$} & - & 19.80 & \multicolumn{2}{|c|}{$0.72^{* *}$} & - & [29] \\
\hline Olives / Oliwki & $67.62 \div 88.60$ & 4.87 & 2.24 & 15.48 & - & - & - & - & {$[34]$} \\
\hline $\begin{array}{l}\text { M28 Tomatoes } \\
\text { Pomidory M28 }\end{array}$ & $83.68 \div 96.87$ & 1.40 & 7.19 & 0.46 & - & - & - & - & {$[36]$} \\
\hline Capers / Kapary & $62.05 \div 75.36$ & - & 33.15 & - & - & - & - & - & [48] \\
\hline
\end{tabular}

Explanatory notes / Objaśnienia:

${ }^{*}$ - values for $\beta+\gamma$-tocopherols / wartości dla $\beta+\gamma$-tokoferoli; ${ }^{* *}$ - values for $\beta+\gamma$-tocotrienols / wartości dla $\beta+\gamma$ - tokotrienoli.

\section{Vitamin E at postharvest}

Vitamin E is affected by processing, storage and cooking of fresh, frozen and canned fruits and vegetables. Little research has taken place on the content of vitamin $\mathrm{E}$ in canned fruit and vegetables as they are not a significant source of the vitamin except for sweet potatoes, spinach and tomato products. Tomatoes have been analysed the most, with evidence showing that the levels of vitamin $\mathrm{E}$ are high in processed tomato products [41]. Abushita et al. [1] showed that tomato cultivars for processing had increased $\alpha$-tocopherol (166\% higher wet matter on average) compared with tomatoes consumed fresh. Processed tomato cultivars to paste showed loss of $20.3 \%$ of $\alpha$-tocopherol. A rise in $\alpha$-tocopherol was observed when raw material was initially heated, but degradation was observed when heating continued. Heating leads to $\alpha$-tocopherol release, however once the maximum amount is released from the cells, $\alpha$-tocopherol concentration declines due to thermal degradation [1]. In a model reaction 
$\alpha$-tocopherol was very stable against thermal treatment. There were no dramatic differences in $\alpha$-tocopherol content in tomato juice, sunflower oil and a mixture of both when heated at $180^{\circ} \mathrm{C}$ for $1 \mathrm{~h} \mathrm{[43].} \mathrm{Further} \mathrm{research} \mathrm{is} \mathrm{needed} \mathrm{to} \mathrm{explain} \mathrm{the} \mathrm{structure}$ of $\alpha$-tocopherol in tomatoes and the effects of processing [1]. United States Department of Agriculture (USDA) data currently support the result that canned products generally contain significant levels of vitamin $\mathrm{E}$ if they are compared with fresh and frozen counterparts. Asparagus is the only vegetable researched that showed significantly lower amounts of vitamin $\mathrm{E}$ in the canned form compared with the fresh product.

The analysis of cooking broccoli showed that all cooking methods lead to a significant release of $\alpha$-tocopherol in fresh broccoli, while there was no relevant change in frozen broccoli [39]. However, this was not the case in foods subjected to strongly oxidative conditions (roasted steak, peas stewed in metal pot) [46]. It is possible that the most common heat treatments, such as broiling or roasting, cause a high loss of vitamin E. Vitamin E content in food treated in vegetable oil increases or remains stable, because vegetable oils are a good source of vitamin E [28]. On the other hand, frequently used vegetable oils for frying decrease the content of vitamin E. Probably microwave heating influences vitamin $\mathrm{E}$ content in vegetable oils the most, although the stage of degradation depends on the type of oil used. In addition, vitamin $\mathrm{E}$ is unstable in the presence of oxygen, light and peroxides (occurring as a result of unsaturated fat auto-oxidation). Retention of vitamin $\mathrm{E}$ is in the range of $60 \div 93 \%$ in legumes [28].

\section{Genetic regulation of vitamin $\mathbf{E}$}

Genetic and genomic tools in the model plant Arabidopsis thaliana (L.) Heynh have contributed towards the identification of vitamin E biosynthetic genes [53], as well as other plants such as Nicotiana tabacum L. and Lactuca sativa L. [52]. In recent studies, there have been identified vitamin $\mathrm{E}$ biosynthetic genes in a number of fruit crop species such as tomato [36], apple [42], mango [45], palm fruit [49], as well as olive [20, 21, 22].

Vitamin E originates from 4-hydroxyphenylpyruvic acid (HPP), homogentisic acid (HGA), geranylgeranyl diphosphate, phytol and phytyl phosphate (phytyl-P), which is derived from either the shikimate acid pathway, the methylerythritol phosphate pathway (MEP) or chlorophyll degradation, respectively. Phytyl diphosphate (phytylPP) is generated either from geranylgeranyl diphosphate (GGPP) being reduced by geranylgeranyl reductase or by phytol after phosphorylation by phytol kinase (VTE5). HPP becomes HGA by 4-hydroxyphenylpyruvate dioxygenase (HPPD), a precursor used for tocochromanols. HGA is decarboxylated and then condensated with the use of a phytyl diphosphate (Phytyl-PP) into 2-methyl-6-phytylbenzoquinol (MPBQ) by homogentisate phytyl transferase (VTE2). The MPBQ is catalyzed into 2,3-dimethyl-6- 
phytyl-1,4-benzoquinol (DMPBQ) by 2-methyl-6-phytyl-1,4-benzoquinol methyl transferase (VTE3) and then to $\gamma$-tocopherol by tocopherol cyclase (TC or VTE1) or to $\delta$ tocopherol directly by TC. With the use of $\gamma$-tocopherol methyltransferase $(\gamma$-TMT or VTE4), $\gamma$ - and $\delta$-tocopherols are metabolized into $\alpha$ - and $\beta$-tocopherols. HGA can also be metabolized into 2-methyl-6-geranylgeranylbenzoquinol (MGGBQ) by homogentisate geranylgeranyl transferase (HGGT) and then is catalyzed to $\delta$-tocotrienol by tocopherol cyclase (VTE1) and afterwards to $\beta$-tocotrienol by $\gamma$-tocopherol methyltransferase (VTE4). The change of MGGBQ into 2,3-dimethyl-6-geranylgeranyl-1,4benzoquinol (DMGGBQ) in addition to the reactions catalyzed by VTE1 and VTE4 is required by the biosynthesis of $\gamma$-tocotrienol and subsequently $\alpha$-tocotrienol (Fig. 3 ).

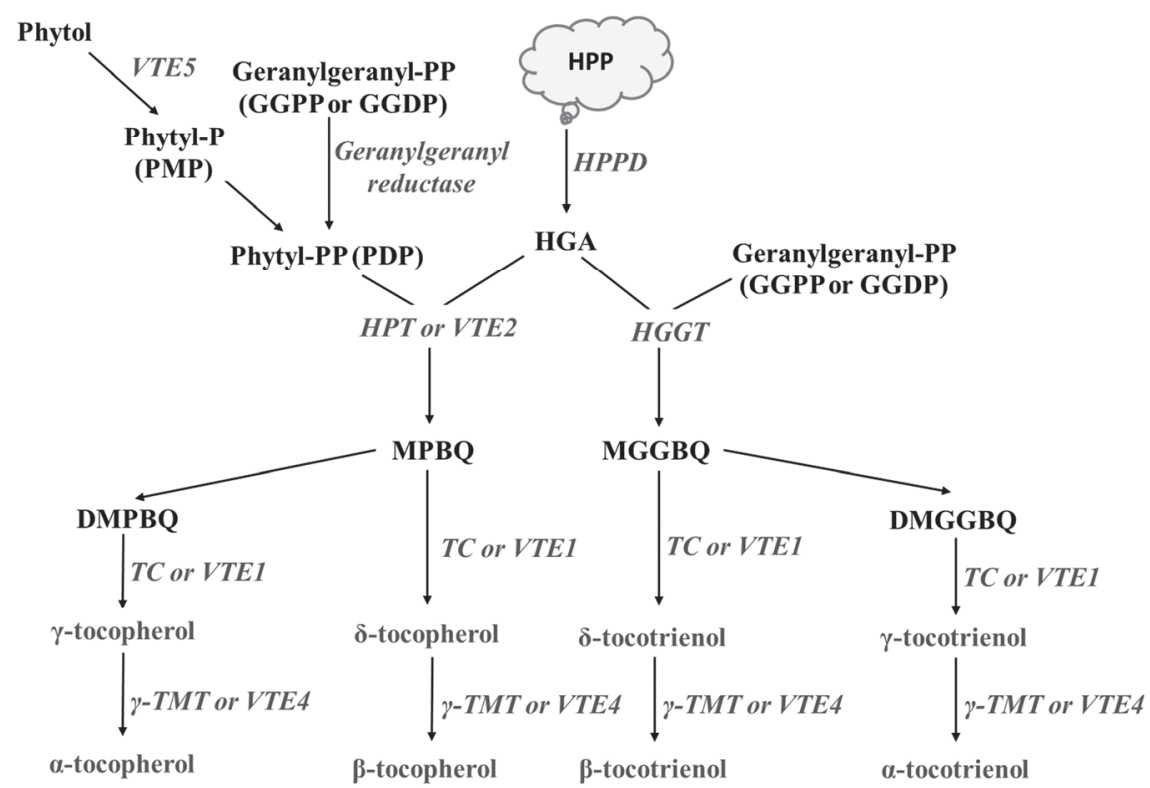

Explanatory notes / Objaśnienia:

Enzymes/genes: HPPD - p- or 4-hydroxyphenylpyruvate dioxygenase; HPT or VTE2 - homogentisate phytyltransferase or vitamin E2; geranylgeranyl reductase; VTE5 - phytol kinase or vitamin E5; phytyl phosphate kinase; HGGT - homogentisate geranylgeranyl transferase; MPBQ MT or VTE3 - 2-methyl-6phytyl-1,4-benzoquinol methyl transferase or vitamin E3; TC or VTE1 - tocopherol cyclase or vitamin E1; $\gamma$-TMT or VTE4 - $\gamma$-tocopherol methyl transferase or vitamin E4. Metabolites: phytol; phytyl-P or PMP phytyl phosphate; phytyl-PP or PDP - phytyl diphosphate; GGPP or GGDP - geranylgeranyl pyrophosphate or geranylgeranyl diphosphate; HPP - p- or 4-hydroxyphenylpyruvic acid; HGA - homogentisic acid; MPBQ - 2-methyl-6-phytylbenzoquinol; DMPBQ - 2,3-dimethyl-6-phytyl-1,4-benzoquinol; MGGBQ - 2-methyl-6-geranylgeranylbenzoquinol; DMGGBQ - 2,3-dimethyl-6-geranylgeranyl-1,4benzoquinol; $\alpha$-, $\beta$-, $\gamma$-, $\delta$-tocopherols; $\alpha$-, $\beta$-, $\gamma$-, $\delta$-tocotrienols.

Fig. 3. Tocochromanol biosynthetic pathway

Rys. 3. Szlak biosyntezy tokochromanolu

Source / Źródło: the study based on [20, 22] / opracowanie na podstawie [20, 22] 
There is relatively little available research on the regulation of tocochromanol biosynthesis in fruits. Geranylgeranyl diphosphate (GGDP) is a popular precursor for tocochromanols and carotenoids. In detail, if the carotenoid biosynthetic pathways in the fruit are altered, then most possibly tocochromanol levels in this organ will also alter. This was observed in tomato fruit that was overexpressing a fruit phytoene synthase and accumulated more $\alpha$-tocopherol [18]. However, the mechanisms, that caused the increased levels of vitamin E content in the fruit, are not apparent. A cause could be the light regulation of tocopherols in the fruit through the transcriptional activation of tocopherol biosynthetic genes (geranylgeranyl reductase and $\gamma$-TMT), which is found in the DE-ETIOLATEDI (DET-1) defective tomato transgenics, which accumulate 2- to 10-fold more tocopherol [15]. Nonetheless, the DET-1 mutation affects carotenoid biosynthesis, plastid biogenesis and other secondary metabolites. Therefore, it is possible that tocopherol content is altered due to fruit metabolism or an effect on plastid compartment size.

Near the breaker stage, when tocochromanol concentration is highest, a close correlation is observed with VTE5 expression profile. VTE5 transcript levels were upregulated during the period of mesocarp development but were suppressed at the breaker stage and through the period of ripening in olive fruit [20]. Similar results were observed in tomato fruit [36]. This drop restricts the phytol diphosphate (phytyl-PP, PDP) input supply toward VTE biosynthesis [36] and is associated with the low concentrations of tocochromanols in olive fruit during ripening, showing that VTE5 is a key component in the biosynthesis of vitamin $\mathrm{E}$ in olive fruit and is considered as a potential marker gene in relevant studies. In mango tocopherol concentration is correlated with transcript levels for HPPD, which is a catalyst in chromanol head group synthesis. Moreover, the Mangifera indica p-hydroxyphenylpyruvate dioxygenase (MiHPPD) expression is ethylene-inducible. Singh et al. [45] have found that the accumulation of vitamin in climacteric fruits during fruit ripening is developmentally controlled and submitted to hormonal regulation by ethylene. Georgiadou et al. [22] found that two Greek cultivars ('Kalokairida' and 'Lianolia Kerkyras') presented the highest vitamin E content, while cv. 'Lianolia Kerkyras' showed high tocochromanol content (especially $\alpha$-tocopherol) and the highest overall antioxidant activity in all developmental stages, concomitant with an up-regulation expression profile of $H P P D$.

There are two methods used to increase the content of vitamin $\mathrm{E}$ in crops, namely plant breeding and metabolic engineering strategies [17, 47]. Levels of vitamin E can differ significantly both between plant species and within species (i.e., among cultivars), meaning that traits the nutritional value can be enhanced by exploiting micronutrient enrichment [50]. The combination of comprehensive molecular mapping and high-throughput phenotyping methods contribute towards the exploitation of this variability, to use as an efficient selection process [47]. Vitamin levels could be enhanced 
by altering external stimuli (light exposure, temperature) via agronomic practices [31]. Another method to increase the contents and stability of vitamins in vegetables are treatments with plant growth regulators and/or elicitors. For instance, ethylene activates phydroxyphenylpyruvate dioxygenase during the ripening of climacteric fruits and consequently increases vitamin E levels [45]. Contrarily, the use of organic fertilizers does not appear to have a significant impact on tocopherol levels [6]. However, vitamin levels in plants were increased by chemical synthesis or fermentation, such as postharvest supplementation [14]. The nutritional quality of products at low cost can be further improved by the application of moderate stresses through agronomic practices (without effects on production).

The modification of genes involved in biosynthesis, recycling, transport, stability, catabolism or control of vitamin E amounts in plants is the basis of relevant metabolic engineering approaches [17]. In Arabidopsis, canola and soybean metabolic engineering of vitamin E has been achieved by expressing both Synechocystis bifunctional prephenate dehydrogenase (tyr $A$ ) and plant HPPD genes, resulting in an increase of 1.8 2.6 times in tocochromanol amounts in seeds [27]. Likewise, the yeast expression (Saccharomyces cerevisiae) prephenate dehydrogenase gene $(P D H)$ in tobacco overexpressing the Arabidopsis HPPD gene resulted in large concentrations of tocotrienols in the leaves [37]. Similarly the yeast PDH and Arabidopsis HPPD genes, expressed in tomatoes under the control of Solanum lycopersicum phosphoenolpyruvate carboxylase 2 (SIPPC2) fruit-specific promoter [16, 24], produce 3 times more tocotrienol concentration in tomatoes [5]. Furthermore, homogentisate phytyl transferase (HPT) overexpression isolated from apple fruit resulted in $1.8 \div 3.6$ fold and $1.6 \div 2.9$ fold rise in tomato leaf of $\alpha$-tocopherol and $\gamma$-tocopherol, respectively, in contrast with the amount of $\alpha$-tocopherol and $\gamma$-tocopherol in the fruit, which increased 1.7- and 3.1-fold, respectively [42].

An optimal approach to enhance the concentration of vitamin $E$ in plants is the manipulation of VTE4 transcript amounts, as it alters both $\delta$ - and $\gamma$-tocopherol to $\beta$ - and $\alpha$-tocopherol, respectively. VTE4 overexpression and naturally amplified $\alpha$-tocopherol accessions present the highest vitamin $\mathrm{E}$ increases independently of the host or the origins of the transgene. When altering pre-existing tocopherols into forms with a strong biological potency, vitamin E activity is improved. Thus, crops modified by VTE4-overexpression demonstrate 5 - 10 times more vitamin E activity than plants that have not been modified. Similarly, Brassica napus VTE4 homolog showed a 50-fold increase in $\alpha$-tocopherol content in transgenic Arabidopsis seeds [19]. VTE4 overexpression also metabolises $\delta$-tocopherol in crops into $\beta$-tocopherol, which is 16.6 -times more bioactive at $50 \%$ of the vitamin E activity of $\alpha$-tocopherol. This method is the most effective in enriching vitamin $\mathrm{E}$ content in crops and has no negative impact in growth and fertility [30]. Overall, the role and regulation of tocochromanols is charac- 
terized by great complexity and further research needs to be conducted using state-ofthe-art systems biology and gene editing approaches in order to fully elucidate their metabolism and function.

\section{Conclusions}

This review brings to light the recent advancements in explaining the different roles of vitamin $\mathrm{E}$ in fruit and vegetables and its importance for health as the human body does not synthesize this vitamin. It also provides an up-to-date account on studies analysing the content and consistency of vitamin $\mathrm{E}$ in different plants and in different tissues during in planta developments as well as post-harvest. Closing, vitamin E major genetic regulatory pathways and future research directions are discussed.

\section{Literatura}

[1] Abushita A.A., Daood H.G., Biacs P.A.: Change in carotenoids and antioxidant vitamins in tomato as a function of varietal and technological factors. J. Agr. Food Chem., 2000, 48(6), 2075-2081.

[2] Aggarwal B.B., Sundaram C., Prasad S., Kannappan R.: Tocotrienols, the vitamin E of the $21^{\text {st }}$ century: Its potential against cancer and other chronic diseases. Biochem. Pharmacol., 2010, 80(11), 1613-1631.

[3] Alagna F., D'Agostino N., Torchia L., Servili M., Rao R., Pietrella M., Giuliano G., Chiusano M.L., Baldoni L., Perrotta G.: Comparative 454 pyrosequencing of transcripts from two olive genotypes during fruit development. BMC Genomics, 2009, 10(1), \#399.

[4] Austin J.R., Frost E., Vidi P.A., Kessler F., Staehelin L.A.: Plastoglobules are lipoprotein subcompartments of the chloroplast that are permanently coupled to thylakoid membranes and contain biosynthetic enzymes. The Plant Cell, 2006, 18(7), 1693-1703.

[5] Baldet P., Ferrand C., Rothan C.: Vitamins in fleshly fruits. In: Fruit Ripening: Physiology, Signalling and Genomics. Eds. P. Nath, M. Bouzayen, A.K. Mattoo, J.C. Pech. CABI Publishing, Wallingford, UK, 2014, pp. 127-150.

[6] Bito T., Ohishi N., Hatanaka Y., Takenaka S., Nishihara E., Yabuta Y., Watanabe F.: Production and characterization of cyanocobalamin-enriched lettuce (Lactuca sativa L.) grown using hydroponics. J. Agr. Food Chem., 2013, 61(16), 3852-3858.

[7] Bodoira R., Torres M., Pierantozzi P., Taticchi A., Servili M., Maestri D.: Oil biogenesis and antioxidant compounds from "Arauco" olive (Olea europaea L.) cultivar during fruit development and ripening. Eur. J. Lipid Sci. Tech., 2015, 117(3), 377-388.

[8] Bruno L., Chiappetta A., Muzzalupo I., Gagliardi C., Iaria D., Bruno A., Greco M., Giannino D., Perri E., Bitonti M.B.: Role of geranylgeranyl reductase gene in organ development and stress response in olive (Olea europaea) plants. Func. Plant Biol., 2009, 36(4), 370-381.

[9] Colombo M.L.: An update on vitamin E, tocopherol and tocotrienol-perspectives. Molecules, 2010, 15(4), 2103-2113.

[10] Conde C., Delrot S., Gerós H.: Physiological, biochemical and molecular changes occurring during olive development and ripening. J. Plant Physiol., 2008, 165(15), 1545-1562.

[11] Dellapenna D., Mène-Saffrané L.: Vitamin E. Adv. Botanical Res., 2011, 59, 179-227.

[12] Dror D.K., Allen L.H.: Vitamin E deficiency in developing countries. Food Nutr. Bull., 2011, 32(2), 124-143. 
[13] Ebong P.E., Owu D.U., Isong E.U.: Influence of palm oil (Elaesis guineensis) on health. Plant Foods Hum. Nutr., 1999, 53(3), 209-222.

[14] Eggersdorfer M., Laudert D., Létinois U., McClymont T., Medlock J., Netscher T., Bonrath W.: One hundred years of vitamins - a success story of the natural sciences. Angew. Chem. Int. Ed., 2012, 51(52), 12960-12990.

[15] Enfissi E.M., Barneche F., Ahmed I., Lichtlé C., Gerrish C., McQuinn R.P., Giovannoni J.J., LopezJuez E., Bowler C., Bramley P.M., Fraser P.D.: Integrative transcript and metabolite analysis of nutritionally enhanced DE-ETIOLATED1 downregulated tomato fruit. The Plant Cell, 2010, 22(4), 1190-1215.

[16] Fernandez A.I., Viron N., Alhagdow M., Karimi M., Jones M., Amsellem Z., Sicard A., Czerednik A., Angenent G., Grierson D., May S., Seymour G., Eshed Y., Lemaire-Chamley M., Rothan C., Hilson P.: Flexible tools for gene expression and silencing in tomato. Plant Physiol., 2009, 151(4), 1729-1740.

[17] Fitzpatrick T.B., Basset G.J.C., Borel P., Carrari F., DellaPenna D., Fraser P.D., Hellmann H., Osorio S., Rothan C., Valpuesta V., Caris-Veyrat C., Fernie A.R.: Vitamin deficiencies in humans: Can plant science help. Plant Cell Online, 2012, 24 (2), 395-414.

[18] Fraser P.D., Enfissi E.M., Halket J.M., Truesdale M.R., Yu D., Gerrish C., Bramley P.M.: Manipulation of phytoene levels in tomato fruit: Effects on isoprenoids, plastids, and intermediary metabolism. The Plant Cell, 2007, 19(10), 3194-3211.

[19] Fritsche S., Wang X., Jung C.: Recent advances in our understanding of tocopherol biosynthesis in plants: An overview of key genes, functions, and breeding of vitamin $\mathrm{E}$ improved crops. Antioxidants, 2017, 6 (4), \#99.

[20] Georgiadou E.C., Ntourou T., Goulas V., Manganaris G.A., Kalaitzis P., Fotopoulos V.: Temporal analysis reveals a key role for VTE5 in vitamin E biosynthesis in olive fruit during on-tree development. Front. Plant Sci., 2015, 6, \#871.

[21] Georgiadou E.C., Goulas V., Ntourou T., Manganaris G.A., Kalaitzis P., Fotopoulos V.: Regulation of on-tree vitamin $\mathrm{E}$ biosynthesis in olive fruit during successive growing years: The impact of fruit development and environmental cues. Front. Plant Sci., 2016, 7, \#1656.

[22] Georgiadou E.C., Koubouris G., Goulas V., Sergentani C., Nikoloudakis N., Manganaris G.A., Kalaitzis P., Fotopoulos V.: Genotype-dependent regulation of vitamin E biosynthesis in olive fruits as revealed through metabolic and transcriptional profiles. Plant Biol., 2019, 21, 604-614.

[23] Grusak M.A., DellaPenna D.: Improving the nutrient composition of plants to enhance human nutrition and health. Annu. Rev. Plant Physiol. Plant Mol. Biol., 1999, 50(1), 133-161.

[24] Guillet C., Aboul-Soud M.A., Le Menn A., Viron N., Pribat A., Germain V., Just D., Baldet P., Rousselle P., Lemaire-Chamley M., Rothan C.: Regulation of the fruit-specific PEP carboxylase Slppc2 promoter at early stages of tomato fruit development. Plos One, 2012, 7(5), \#36795.

[25] Horvath G., Wessjohann L., Bigirimana J., Monica H., Jansen M., Guisez Y., Caubergs R., Horemans N.: Accumulation of tocopherols and tocotrienols during seed development of grape (Vitis vinifera L. cv. Albert Lavallée). Plant Physiol. Biochem., 2006, 44(11), 724-731.

[26] Kanellis A.K., Manganaris G.A.: Antioxidants and bioactive compounds in fruits. In: Fruit ripening: physiology, signalling and genomics. Eds. P. Nath, M. Bouzayen, A.K. Mattoo, J.C. Pech. CABI Publishing, Wallingford, UK, 2014, pp. 99-126.

[27] Karunanandaa B., Qi Q., Hao M., Baszis S.R., Jensen P.K., Wong Y.H.H., Jiang J., Venkatramesh M., Gruys K.J., Moshiri F., Post-Beittenmiller D., Weiss J.D., Valentin H.E.: Metabolically engineered oilseed crops with enhanced seed tocopherol. Metabolic Engineering, 2005, 7(5), 384-400.

[28] Lešková E., Kubíková J., Kováčiková E., Košická M., Porubská J., Holčíková K.: Vitamin losses: Retention during heat treatment and continual changes expressed by mathematical models. J. Food Compos. Anal., 2006, 19(4), 252-276. 
[29] Luby C.H., Maeda H.A., Goldman I.L.: Genetic and phenological variation of tocochromanol (vitamin E) content in wild (Daucus carota L. var. carota) and domesticated carrot (D. carota L. var. sativa). Hort. Res., 2014, 1, \#14015.

[30] Mène-Saffrané L., Pellaud S.: Current strategies for vitamin E biofortification of crops. Curr. Opin. Biotech., 2017, 44, 189-197.

[31] Miller D.D., Welch R.M.: Food system strategies for preventing micronutrient malnutrition. Food Policy, 2013, 42, 115-128.

[32] Munné-Bosch S., Alegre L.: The function of tocopherols and tocotrienols in plants. Crit. Rev. Plant Sci., 2002, 21(1), 31-57.

[33] Munné-Bosch S.: $\alpha$-tocopherol: A multifaceted molecule in plants. Vitam. Horm., 2007, 76, 375392.

[34] Muzzalupo I., Stefanizzi F., Perri E., Chiappetta A.A.: Transcript levels of CHL $P$ gene, antioxidants and chlorophylls contents in olive (Olea europaea L.) pericarps: A comparative study on eleven olive cultivars harvested in two ripening stages. Plant Foods Hum. Nutr., 2011, 66(1), 1-10.

[35] Nesaretnam K.: Multitargeted therapy of cancer by tocotrienols. Cancer Letters, 2008, 269(2), 388395.

[36] Quadrana L., Almeida J., Otaiza S.N., Duffy T., da Silva J.V.C., de Godoy F., Asís R., Bermúdez L., Fernie A.R., Carrari F., Rossi M.: Transcriptional regulation of tocopherol biosynthesis in tomato. Plant Molecul. Biol., 2013, 81(3), 309-325.

[37] Rippert P., Scimemi C., Dubald M., Matringe M.: Engineering plant shikimate pathway for production of tocotrienol and improving herbicide resistance. Plant Physiol., 2004, 134(1), 92-100.

[38] Sakouhi F., Herchi W., Sebei K., Absalon C., Kallel H., Boukhchina S.: Accumulation of total lipids, fatty acids and triacylglycerols in developing fruits of Olea europaea L. Sci. Hortic., 2011, $132,7-11$.

[39] Schlich E., Boeker M., Dietrich J., Loh S., Ziems M.: Cooking parameters and vitamins. Hauswirtschaft und Wissenschaft, 2001, 3, 128-132.

[40] Schneider C.: Chemistry and biology of vitamin E. Mol. Nutr. Food Res., 2005, 49(1), 7-30.

[41] Scott C.E., Eldridge A.L.: Comparison of carotenoid content in fresh, frozen and canned corn. J. Food Compos. Anal., 2005, 18(6), 551-559.

[42] Seo Y.S., Kim S.J., Harn C.H., Kim W.T.: Ectopic expression of apple fruit homogentisate phytyltransferase gene (MdHPT1) increases tocopherol in transgenic tomato (Solanum lycopersicum cv. Micro-Tom) leaves and fruits. Phytochemistry, 2011, 72(4), 321-329.

[43] Seybold C., Fröhlich K., Bitsch R., Otto K., Böhm V.: Changes in contents of carotenoids and vitamin E during tomato processing. J. Agric. Food Chem., 2004, 52(23), 7005-7010.

[44] Shepherd T., Robertson G.W., Griffiths D.W., Birch A.N.E.: Epicuticular wax composition in relation to aphid infestation and resistance in red raspberry (Rubus idaeus L.). Phytochemistry, 1999, 52(7), 1239-1254.

[45] Singh R.K., Ali S.A., Nath P., Sane V.A.: Activation of ethylene-responsive phydroxyphenylpyruvate dioxygenase leads to increased tocopherol levels during ripening in mango. J. Exp. Bot., 2011, 62(10), 3375-3385.

[46] Steinhart H., Rathjen T.: Dependence of tocopherol stability on different cooking procedures of food. Int. J. Vitam. Nutr. Res., 2003, 73(2), 144-151.

[47] Tester M., Langridge P.: Breeding technologies to increase crop production in a changing world. Science, 2010, 327(5967), 818-822.

[48] Tlili N., Nasri N., Khaldi A., Triki S., Munné-Bosch S.: Phenolic compounds, tocopherols, carotenoids and vitamin C of commercial caper. J. Food Biochem., 2011, 35(2), 472-483.

[49] Tranbarger T.J., Dussert S., Joët T., Argout X., Summo M., Champion A., Cros D., Omore A., Nouy B., Morcillo F.: Regulatory mechanisms underlying oil palm fruit mesocarp maturation, ripening, 
and functional specialization in lipid and carotenoid metabolism. Plant Physiol., 2011, 156(2), 564584.

[50] Welch R.M., Graham R.D.: Breeding for micronutrients in staple food crops from a human nutrition perspective. J. Exp. Bot., 2004, 55, 353-364.

[51] Wollen K.A.: Alzheimer's disease: The pros and cons of pharmaceutical, nutritional, botanical, and stimulatory therapies, with a discussion of treatment strategies from the perspective of patients and practitioners. Altern. Med. Rev., 2010, 15(3), 223-244.

[52] Yabuta Y., Tanaka H., Yoshimura S., Suzuki A., Tamoi M., Maruta T., Shigeoka S.: Improvement of vitamin E quality and quantity in tobacco and lettuce by chloroplast genetic engineering. Transgenic Research, 2013, 22(2), 391-402.

[53] Zhang W., Liu T., Ren G., Hörtensteiner S., Zhou Y., Cahoon E.B., Zhang C.: Chlorophyll degradation: The tocopherol biosynthesis-related phytol hydrolase in Arabidopsis seeds is still missing. Plant Physiol., 2014, 166(1), 70-79.

\title{
ZRÓŻNICOWANE ZNACZENIE WITAMINY E, JEJ WYSTEPOWANIE ORAZ FUNKCJE REGULACYJNE W RÓŻNYCH TKANKACH ROŚLINNYCH
}

\author{
Streszczenie
}

Owoce i warzywa zawierają m.in. witaminy, błonnik pokarmowy i fitozwiązki, które sprzyjają zdrowiu człowieka. W szczególności witaminy są głównymi związkami bioaktywnymi, które są rozpuszczalne w wodzie (B i C) lub w tłuszczach (A, D, E i K), wykazujące silny potencjał przeciwutleniający i ograniczające szereg chorób, w tym nowotwory i choroby układu krążenia. Witaminy odgrywają kluczową rolę $\mathrm{w}$ ochronie roślin przed abiotycznymi i biotycznymi czynnikami stresowymi. Witamina E to grupa ośmiu rozpuszczalnych w tłuszczach związków zwanych tokochromanolami, które są syntetyzowane wyłącznie przez organizmy fotosyntetyzujące. Tokochromanole dzieli się na dwie grupy - tokoferoli i tokotrienoli. Każda grupa zawiera cztery formy oznaczone przedrostkami $\alpha-, \beta-, \gamma-\mathrm{i} \delta$-, co daje w sumie osiem form. Witamina $\mathrm{E}$ jest niezbędnym, rozpuszczalnym w thuszczach przeciwutleniaczem $\mathrm{w}$ diecie człowieka, chroniącym przed nowotworami, cukrzycą, chorobami układu krążenia i neurologicznymi. W niniejszym przeglądzie podsumowano najnowsze osiągnięcia w zrozumieniu zróżnicowanego znaczenia witaminy E, a także jej głównych genetycznych szlaków regulacyjnych w roślinach. Ponadto przedstawiono kompleksowe odwzorowanie występowania witaminy $\mathrm{E}$ w różnych tkankach roślin, organellach i gatunkach roślin ogrodniczych, a także na różnych etapach rozwoju owoców i w trakcie zbiorów.

Słowa kluczowe: tokoferole, tokotrienole, tokochromanole, witamina E 